Ігнатов О. M., доиент кафедри крилінального права та крилінологї Одеського державного університету внутрішніх справ

\title{
АКЦЕНТУАЦІЇ ОСОБИСТОСТІ ЯК ФАКТОР ДЕТЕРМІНАЦІЇ ПРОТИПРАВНОЇ ПОВЕДІНКИ
}

Анотація. Стаття присвячена дослідженню ролі акцентуацій особистості як фактору детермінації протиправної поведінки. Поєднання акцентуацій характеру та темпераменту призводить до появи специфічних типів особистості (демонстративна, педантична, застрягаюча та збудлива), кожен із яких має свою криміногенну специфіку, яка визначається спрямованістю відповідного потенціалу особистості.

Ключові слова: акцентуація, особистість, характер, темперамент, протиправна поведінка, злочин.

Постановка проблеми. Психічним аномаліям, зокрема особливостям їх криміногенності, 3 давніх часів приділялася значна увага, перш за все, з боку психіатрів, психологів, сексологів і кримінологів. Даній проблемі присвячені роботи таких учених, як: Ю. М. Антонян, Ю. В. Александров, С. В. Бородін, Л. С. Виготський, П. Б. Ганнушкін, Л. Д. Гаухман, В. В. Голіна, В. В. Гульдан, О. М. Джужа, В. П. Ємельянов, А. П. Закалюк, А. Ф. Зелінський, В. М. Бехтерєв, Г. Б. Калманов, I. І. Карпець, Є. К. Краснушкін, О. М. Леонт'єв, О. Є. Личко, О. Р. Лурія, Г. М. Міньковський, Р. І. Михеєв, В. П. Сербський, Н.С. Таганцев, В. С. Трахтеров, В. О. Туляков, О. Є. Фрейєров, О. О. Ходимчук, В. І. Шакун, Б. В. Шостакович, М. Г. Ярошевський ті інші. Така значна увага з боку фахівців обумовлена багатоаспектністю проблемного поля дослідження. Незважаючи на достатню розробленість даної тематики, враховуючи різні концептуальні підходи вчених, залишається ціла низка питань, що вимагають подальшого дослідження з урахуванням реалій сьогодення. Окремого розгляду заслуговують психічні аномалії у вигляді акцентуацій особистості.

Виклад основного матеріалу дослідження. Дослідженню акцентуацій особистості психіатрія і психопатологія надають великого значення, однак ставлення до даного фактору як серед медиків, так й серед правників неоднозначне. В психіатрії переважає точка зору, відповідно до якої акцентуація особистості є нормою (ії крайнім варіантом). При цьому прихильники такої позиції нерідко указують на схильність осіб з акцентуацією особистості окремих типів до протиправної поведінки, роблячи це 3 обмовкою на властиву таким особам меншу опірність негативній дії мікросередовища [1, с. 19]. Деякі кримінологи також вказують, що акцентуації особистості є крайніми видами психічної норми, з цієї позиції розглядають їх роль у детермінації злочинної поведінки [2, с. 161].

У свою чергу, як справедливо відзначає Ю.П. Бойко, на підставі думки про акцентуацію як норму, в процесі медичного обстеження делінквентів робиться висновок про їх нормальний психічний стан, що у результаті призводить або до невірної кваліфікації діяння, або несправедливому покаранню, що не враховує психотичні особливості людини. Спостерігається зростання злочинів, вчинених особами, психічний стан яких характеризується як граничний між осудністю і неосудністю. Про це свідчить кількість стаціонарних експертиз осіб, що вчинили злочини в такому стані, що зростає з року в рік [3, с. 76, 129].

Як указував К. Леонгард, акцентуація завжди загалом припускає посилення ступеня певної риси. Така риса особистості стає акцентуйованою. Акцентуйовані риси не такі численні, як варіюючі індивідуальні. Акцентуація це ті ж індивідуальні риси, яким властива тенденція до переходу в патологічний стан. При більшій виразності вони накладають відбиток на особистість як таку i, нарешті, можуть набувати патологічного характеру, руйнуючи структуру особистості [4, с. 15-16].

Акцентуація особистості має істотне значення при формуванні моделі поведінки індивіда, при цьому поряд 3 позитивним потенціалом вони можуть мати і негативний потенціал (як щодо соціальної адаптації в цілому, так і щодо конкретних поведінкових актів зокрема), що особливо актуально в контексті вивчення злочинної поведінки. Фахівці указують, що від 20 до 50\% населення мають акцентуйовані риси характеру, що може призводити до нервових зривів, конфліктів, неадекватних реакцій та інших відхилень у поведінці [5, с. 292].

Кримінологи прямо вказують на те, що на вибір злочинної поведінки істотно впливає вид акцентуації особистості [6, с. 106]. Так, Ю.М. Антонян і С.В. Бородін на підставі проведених досліджень указують, що акцентуація володіє високим криміногенним потенціалом, а питома вага акцентуантів серед злочинців порівняно велика. Частина осіб, що мають нестійку, інертно-імпульсну, гіпертимну і демонстративну акцентуації серед злочинців на 20-30\% вище, ніж серед осіб, що не вчиняли злочинів [7, с. 15]. Згвалтування, садизм, вбивство найчастіше вчинюють особи з епілептоїдною психопатією або акцентуацією особистості того ж типу або олігофрени; педофілія характерна для осіб з нестійкою і астенічною психопатією, ефебофілія - для істероїдних осіб; особи з астенічними i психоастенічними рисами в більшості випадків беруть участь в груповому і не вчинюють індивідуального згвалтування [8, с. 179].

Результати сучасних вітчизняних досліджень [9, с. 1113] також вказують на наявність у значної частки злочинців, зокрема сексуальних злочинів, різного роду акцентуацій особистості (провідних особистісних радикалів: нестійкого, епілептоїдного, істероїдного, гіпертимного тощо та типологічних особливостей особистості). 
У акцентуйованих особистостях потенційно закладені як можливості соціально позитивних досягнень, так і соціально негативний заряд. Так, застрягаюча особистість при несприятливих обставинах може стати незговірливою, такою, що не терпить заперечень, але якщо обставини сприятимуть такій людині, не виключено, що вона виявиться невтомним і цілеспрямованим трудівником. Педантична особистість при несприятливих обставинах може захворіти неврозом нав'язливих станів, при сприятливих - 3 неї вийде зразковий працівник з великим відчуттям відповідальності за доручену справу. Демонстративна особистість може розіграти перед вами рентний невроз, при інших обставинах вона здатна виділитися видатними творчими досягненнями. При негативній картині лікарі схильні убачати психопатію, при позитивній - швидше акцентуацію особистості. Подібний підхід в достатній мірі виправданий, оскільки легкий ступінь відхилень пов'язаний частіше 3 позитивними проявами; а висока - 3 негативними [4, с. 17$]$.

Акцентуації особистості обумовлюють уразливість особистості щодо не будь-яких, а лише щодо певного роду психотравмуючих впливів, адресованих так званому місцю найменшого опору певного типу характеру, при збереженні стійкості до інших [10, с. 90]. Так, наприклад, за даними Психоневрологічного інституту ім. В.М. Бехтерєва, у 96\% правопорушників з акцентуацією особистості (найбільший ризик правопорушень встановлений при нестійкій і епілептоїдній формі) в 76\% випадків була відмічена слабка турбота 3 боку батьків разом 3 емоційним відкиданням [2, с. 163]. Саме у зв'язку з можливими негативними проявами акцентуації особистості в поведінці людини, які в певних умовах і зовнішній обстановці можуть детермінувати злочинну поведінку, даний різновид психічних аномалій повинен знаходитися у полі зору кримінологів 1 інших дослідників злочинності.

Численними дослідженнями (П.Б. Ганнушкін [11], К. Леонгард [4], О.С. Личко [1], В.В. Юстицький [12] і ін.) виявлені основні типи акцентуацій. В цылому можна виділити наступні основні типи акцентуації особистості: інтравертний (шизоїдний) тип - для нього властива замкнутість в спілкуванні і встановленні контактів з тими, що оточують і відхід в себе; екстравертний (конформний) mun - емоційна напруженість, украй актуалізована потреба в спілкуванні і діяльності, часто безвідносно до ії необхідності і цінності, балакучість, непостійність захоплень, іноді хвалькуватість, поверхневість, конформність; некерований (ригідно-афектний, епілептоїдний, експлозивний, збудливий) тип - імпульсивність, конфліктність, схильність до коротких періодів злісно-тужливого настрою 3 накипаючим роздратуванням, афектна вибуховість до нестримної люті, нетерпимість до заперечень, владність 3 тими, хто оточують, іноді і підозрілість, ваговитість поведінки; демонстративний тип (гістрионічний, істероїднй, істеричний - при більш вираженій акцентуащіі) акцентуації особистості властивий егоцентризм, актуалізована потреба в постійній увазі до своєї персони, захопленні і співчутті, схильність до позерства; неврастенічний (неконцентрований, астено-невротичний) тип, його переважаючі риси - це дратівливість, підвищена стомлюваність, недовірливість; сенситивний (боязливий) тип - йому властиві лякливість, замкнутість, соромливість; емотивний (афективно екзальтований, емоиійно-лабільний) тип - це крайня мінливість настрою, перепади настрою від нікчемного приводу, сильна прихильність до людей, украй актуалізована потреба в емоційних контактах, співпереживанні, схильність до невротичних реакцій при труднощах і неприємностях; нестійкий (слабовільний) тип - безперервна підвищена тяга до задоволень, розваг, неробства, безініціативність, прагнення уникнути будь-яких труднощів, відсутність справжньої прихильності до інших людей, боязкість тощо.

Слід зазначити, що сьогодні, в умовах ускладнення ситуації щодо психічного здоров'я населення, особливе занепокоєння викликає частка у всій масі психічних аномалій саме акцентуацій особистості, особливо у молодого покоління. Так, дослідження граничних нервово-психічних (невротичних та неврозоподібних) розладів у підлітків показало наступне. При невротичних та неврозоподібних розладах патопсихологічне обстеження у $100 \%$ підлітків виявило такі особливості, як емоційна лабільність, формування порушень на тлі акцентуацій особистості того чи іншого типу, хитлива неадекватна самооцінка, виражена потреба в самовизнанні, самоствердженні. Характер психічної травматизації змінюється в бік збільшення питомої ваги тривалої психічної напруги, викликаної індивідуальними, особистими психотравмами, що мають відбиток різкої зміни соціально-економічних, матеріальних і психологічних факторів. Психотравмуючі обставини об'єктивно менш тяжкі й інтенсивні, але більш неповторні, складні й неоднозначні для особистості. Зміна патогенетичних факторів, які беруть участь у клінічному оформленні й динаміці невротичних і неврозоподібних розладів виявляється в зростанні соматичної, ендокринної, органічної патології, що сприяє трансформації біологічної реактивності хворих. Специфічними особливостями для хворих 3 порушеннями поведінки $є$ наявність епілептоїдного $(23,1 \% \pm 6,7 \%)$ і шизоїдного $(17,9 \% \pm 6,1 \%)$ типів акцентуації особистості, вираженої $(46,2 \% \pm 7,9 \%)$ i сильної $(25,6 \% \pm 6,9 \%)$ реакції емансипації, низької або високої конформності, ознак можливого розвитку психопатії $(48,7 \% \pm 8,0 \%)$, психологічної схильності до алкоголізації $(61,5 \% \pm 7,8 \%)$ і делінквентності $(76,2 \% \pm 1,0 \%)$, вираженої соціальної дезадаптації [13, с. 12-13; 14].

Зі всього різноманіття акцентуацій найбільш криміногенними є збуджувані. Для неї характерними є збудженість, некерованість, мстивість, жорстокість, схильність для алкоголізму та наркотикам. Такими особами вчинюються насильницькі злочини. Для осіб з гіпертимною акцентуацією притаманні: товариськість, брехливість та авантюризм. Вони схильні до алкоголізму. Для параноїальної акцентуації характерними є такі якості як егоїзм, злопам'ятливість, афективні переживання. Для демонстративних (істероїдних) такими якостями є брехливість, схильність до ризику, театральність поведінки. Цими особами найчастіше вчинюються такий злочин, як шахрайство. Серед правопорушників поширена нестійка (лабільна) акцентуаиія. Для неї характерна часта зміна настрою від збудження до депресії. Особи 3 такою акцентуацією $€$ слабовільними, схильними до зовнішніх впливів. Eniлептоїдному типу акцентуації особистості притаманні егоїстичність, властолюбство у поєднанні з недоброзичливим ставленням до оточення. В основі недоброзичли- 
вого ставлення лежать дріб'язковість, образливість і дратівливість. Мотиваційна сфера таких осіб відзначається розгальмованістю, переважанням органічних, зокрема статевої, та примітивних за способом задоволення потреб. Особистість із епілептоїдним типом акцентуації схильна до вчинення імпульсивних насильницьких злочинів 3 проявами жорстокості: вбивство з особливою жорстокістю, мордування, катування тощо. Істероїдний тип акцентуації особистості відзначається егоїзмом, демонстративністю, брехливістю, інфантилізмом (вередуванням), намаганням всіляко накинути оточенню визнання власної винятковості. Якщо це не сприймається оточенням, то у особи виникає дратівливість, нетерпимість до тих, хто ії не визнає, не підтримує та не поважає. Така особистість схильна до симуляцій самовбивства, нанесення самій собі поранень демонстративно, скоєння злочинів як засобу привернути до себе увагу, висунути певні вимоги до суспільства тощо (наприклад, захоплення заручників) [6, с. 100-101]. Дослідники також вказують на специфіку криміногенного значення акцентуацій відносно окремих типів злочинців, зокрема, неповнолітніх злочинців. Так, наприклад, підчищений суб'єктивізм в оцінці оточення, нездатність до співпереживання, труднощі при соціалізації, що супроводжуються «ідейним» бродяжництвом і дармоїдством, правопорушеннями у боротьбі за «справедливість» або 3 метою самоствердження в групі однолітків притаманні шизоїдам. Тривожність, невпевненість і страхи психостеніків нерідко компенсуються зловживанням алкоголем, наркотиками. Експлозивному (епілептоїдному) типу властива схильність до бурхливих афективних реакцій, які супроводжуються вегетосудинною нестійкістю, проявами агресії та аутоагресії. Некритичне ставлення до власної поведінки, гострі реакції емансипації, грубість, цинізм у поєднанні зі здатністю до легкого навіювання у сукупності можуть зумовити серйозні прояви антигромадської поведінки тощо [15, с. 310-311; 16, с. 50-72].

Слід враховувати, що залежно від ступеня виразності розрізняють явні і приховані (латентні) акцентуації особистості, що можуть переходити одна в одну під впливом різноманітних чинників [10, с. 90$]$.

Як відзначав Д. Леонгард, якщо в структурі людської особистості розрізняти властивості характеру і темпераменту, то в розглянутих вище типах акцентуації особи переважають властивості характеру. Властивостями характеру визначаються спрямованість інтересів людини i форма іiі реакцій, тоді як від темпераменту залежать темп і глибина емоційних реакцій. Чіткої межі між темпераментом і характером, проте, не існує. Однак численні поєднання акцентуацій характеру та темпераменту (при домінуванні перших) призводить до появи специфічних типів особистості, основні з яких: демонстративна, педантична, застрягаюча та збудлива [4, с. 102].

Кожний із зазначених типів особистості, як вказує 0.0. Юхно [6, с. 101-103] має свою криміногенну специфіку, яка визначається спрямованістю відповідного потенціалу особистості. Наведемо надану вказаним автором відповідну характеристику кожного типу.

Так, для демонстративної особистості притаманними $€$ наступні риси: висока адаптивність, схильність до перевтілень, авантюризму; емоційна чутливість, глибокі та яскраві емоційні переживання; легке витіснення зі свідомості та швидке забування неприємних ситуацій із власного життя; впадання у психопатоподібні стани (образливість, істерика, скандалізм). При несприятливих соціальних обставинах така особистість: вдається до витонченої, переконливої брехні, причому вона сама починає в це вірити; перевтілюється у невинну жертву, обдаровану, геніальну людину, якій заздрять; безпорадну людину, що потребує підтримки та опіки; скоює авантюрні, імпульсивні вчинки, не боячись заподіяти собі шкоди. Демонстративна особистість схильна до вчинення злочинів за мотивами ствердження, самоствердження та ризику. Такими особами вчиняються насильницькі та корисливо-насильницькі злочини.

Педантична особистість характеризується такими рисами, як: нерішучість, боязкість, ретельне обдумування та перевірка своїх вчинків; нав'язливі психічні стани та ідеї (дріб'язковість, страхи, перебільшення погроз, іпохондрія - зануреність у стан власного здоров'я); тривале переживання неприємних подій, погане витіснення їх із свідомості. У разі несприятливого соціального розвитку така особистість: всіляко намагається уникнути невизначеності, небезпеки, динамічних і мало прогнозованих ситуацій; $є$ надвимогливою до себе та оточення (підлеглих, членів сім'ї тощо) щодо виконання обов'язків, порядку, акуратності; посилено піклується про власне здоров'я, боїться хвороб, перебільшує тяжкість наявних хвороб. Для педантичної особистості злочин виступає наслідком відставання в чомусь від інших, пасивності, несвоєчасних і помилкових дій. Такі особи часто вчиняють необережні злочини.

Застрягаюча особистість відзначається такими особистісними рисами: цілеспрямованість, упертість, егоїстичність; яскраво виражене честолюбство, самовпевненість у поєднанні з образливістю; сильні, несподівано спалахуючі емоції та почуття (до рівня афекту), які переживаються тривалий час і періодично повторюються. У разі несприятливого соціального розвитку така особистість може: висувати «надцінні» ідеї й пропозиції та вперто, всілякими способами домагатися їх визнання; намагатися досягти реальних, а не показових успіхів за будь-яку ціну; періодично впадати в стани підозрілості, ревнощів, мстивості, подавати судові позови з різних, навіть дріб'язкових, причин; знаходити собі кумира, котрому фанатично буде поклонятися і заради нього буде готова здійснити будь-який вчинок. Злочини, що вчиняються такими особами характеризуються мотивами відчуження, розрядки та компенсації негативних емоцій та почуттів. Наприклад, вбивство з хуліганських мотивів, хуліганство або так званий вандалізм.

Для збудливої особистості притаманним є: підвищена чутливість, запальність, дратівливість; посередній інтелект, уповільнене мислення (тупоумство), знижена моральна і правова регуляція поведінки; різка зміна емоційних станів (похмурість - гнів; похмурість - радість), бурхливих за силою виразу і нетривалих у часі. За несприятливого соціального розвитку збудлива особистість: скоює різноманітні імпульсивні вчинки; раптове зникнення 3 сім'ї, вечірки з друзями; зміна професійної діяльності чи професійного оточення; проявляє нерозбірливість у задоволенні потреб (їжа, напої, інтимні стосунки, випадкові знайомства і компанії); невдоволення чимось або кимсь 
виражає у брутальній, агресивній формі (фізична та словесна відверта агресія). Збудлива особистість схильна до скоєння злочинів за аморальними, збоченими мотивами та мотивами розрядки і компенсації негативних емоцій, наприклад вбивство $з$ помсти [6, с. 101-103].

Висновки. Таким чином, акцентуації особистості має істотне значення при формуванні моделі поведінки індивіда, при цьому наряду з позитивним потенціалом вони можуть мати і негативний потенціал (як щодо соціальної адаптації в цілому, так і щодо конкретних поведінкових актів), що особливо актуально в контексті вивчення злочинної поведінки. Поєднання акцентуацій характеру та темпераменту призводить до появи специфічних типів особистості (демонстративна, педантична, застрягаюча та збудлива), кожен із яких має свою криміногенну специфіку, яка визначається спрямованістю відповідного потенціалу особистості. Саме у зв'язку з можливими негативними проявами акцентуацій особистості в поведінці людини, які в певних умовах і зовнішній обстановці можуть детермінувати злочинну поведінку, даний різновид психічних аномалій повинен знаходитися у полі зору кримінологів і інших дослідників злочинності. Врахування впливу акцентуації дозволяс глибше вивчити психотичні та інші, що сформувалися під їх впливом, особливості особистості злочинця, вивчити мотиви і мотивацію його протиправної поведінки, а, отже, визначити з урахуванням особистості злочинця найбільш ефективні кримінально-правові і інші заходи впливу на нього.

\section{Jimepamypa:}

1. Личко А.Е. Психопатии и акцентуация характера у подростков Изд. 2-е доп. и перераб. / А.Е. Личко. - Л.: Медицина, 1983. -256 с.

2. Кузнецова Н.Ф. Проблемы криминологической детерминации / Под ред. В.Н. Кудрявцева. - М.: Изд-во Моск. ун-та, 1984. - С. 163. (200 c.).

3. Бойко Ю.П. Уголовная ответственность лиц с пограничным состоянием психики: дисс. ... канд. юрид. наук: 12.00.08 / Ю.П. Бойко. - М., 2005. - 145 с.

4. Леонгард К. Акцентуированные личности / К. Леонгард : / Пер. с нем. (ГДР, Народ и здоровье, 1976 г.). - К.: Вища школа. Головное изд-во., 1981. - 392 с.

5. Психология и педагогика: Учебное пособие / Под. ред. А. Абульхановой, Н.В. Васиной, Л.Г. Лаптевой, В.А. Сластенина. - М.: Совершенство. $-1998 .-320$ с.

6. Кримінологія. (Загальна частина): Підручник / Кол. авторів Блага А.Б., Богатирьов І.Г., Давиденко Л.М. та ін.; за заг. ред. О.М. Бандурки. - Харків: Вид-во ХНУВС, 2010. - 280 с.

7. Антонян Ю.М., Бородин С.В. Преступное поведение и психические аномалии / Под ред. В. Н. Кудрявцева. - М.: Издательство «Спарк», 1998. - 215 с.

8. Гульман Б.Л. Сексуальные преступления / Б.Л. Гульман. - Харьков: Рубикон, 1994. - 276 с.

9. Зайцев О.О. Психічна патологія в осіб молодого віку, які скоїли сексуальні злочини (діагностика, клініка, лікування та профілактика): Автореф. дис. ... д-ра. мед. наук: 14.01.16 / О.О. Зайцев. - K., 2005. -30 c.

10. Коновалова В.О. Юридична психологія : [академічний курс : підруч. для вищ. навч. закл.] / В.О. Коновалова, В.Ю. Шепітько - К.: Концерн «Видавничий Дім «Ін Юре», 2004. - 424 с.

11. Ганнушкин П.Б. Клиника психопатий, их статика, динамика и систематика / П.Б. Ганнушкин. - Новгород: НГМА, 1998. - 128 с.

12. Юстицкий В.В. Роль учения об акцентуациях характера в анализе взаимосвязей между психологическими качествами правонарушителя (на примере эпилептоидной акцентуации) / В.В. Юстицкий // Сборник научных работ. - Вильнюс: Изд-во НИИСЭ МЮ ЛитССР. - 1980. - Вып. 6. - С. 275-285

13. Матковська Т.М. Сучасний патоморфоз невротичних та неврозоподібних розладів у підлітків: Автореф. дис...канд. мед. наук: 14.01.16 / Т.М. Матковська. - Х., 2002. - 20 с.

14. Матковская Т.Н. Невротические расстройства у подростков в современном социуме / Т.Н. Матковская // Український вісник психоневрології. - 2002. - Т. 11, вип. 32. - С. 116-118.

15. Герасимів Т.З. Природні та соціальні детермінанти формування девіантної поведінки людини: філософсько-правовий вимір): дис. ... доктора юрид. наук: 12.00 .12 / Т.3. Герасимів. - Львів, 2010. -458 c.

16. Кондрашенко В.Т. Девиантное поведение у подростков: социально-психологический и психиатрический аспекты / В.Т. Кондрашенко. - Минск, 1988. - С. 50-72.

Игнатов А. Н. Акцентуации личности как фактор детерминации противоправного поведения

Аннотация. Статья посвящена исследованию роли акцентуаций личности как фактора детерминации противоправного поведения. Сочетание акцентуаций характера и темперамента приводит к появлению специфических типов личности (демонстративная, педантичная, застревающая и возбудимая), каждый из которых имеет свою криминогенную специфику, определяемую направленностью соответствующего потенциала личности.

Ключевые слова: акцентуация, личность, характер, темперамент, противоправное поведение, преступление.

Ignatov $O$. Accentuations of personality as factor of determination of illegal behavior

Summary. The article is sanctified to research of role of accentuations of personality as a factor of determination of illegal behavior. Combination of accentuations of character and temperament results in appearance of specific types of personality (demonstrative, pedantic, sticking and excitable), each of which has the criminogenic specific determined by the orientation of corresponding potential to personality.

Key words: accentuation, personality, character, temperament, illegal behavior, crime. 